and Part 2 of the costing returns of hospitals for the year ending March 31, 1935 (H.M. Stationery Office, 1936. Price 1s. and 1s. 3d. net). Part I contains particulars of Poor Law hospitals, general hospitals administered by local authorities under the Public Health Acts or the Local Government Acts, sanatoria and other institutions for the residential treatment of tuberculosis, and maternity homes and hospitals. Part 2 contains the similar particulars for Poor Law institutions and separate casual wards.

\section{Research at the London Hospital}

THe annual volume of "Researches Published from the Wards and Laboratories of the London Hospital during 1935" has recently been issued (London: H. K. Lewis and Co., Ltd., 136 Gower Street, W.C.1. Price $7 s .6 d$. net). The matter has been selected and issued by the Publications Committee for Researches from the London Hospital, of which Prof. Bedson is honorary secretary. The volume includes twentyseven papers, all published in various current journals, which cover a wide range of subjects included in the science and art of medicine.

\section{A Large Sunspot}

THE rising solar activity continues to yield, amongst other phenomena, a fairly high frequency of sunspots -about six groups a day being visible. These groups are usually of moderate extent, but about a dozen seen since the beginning of 1936 may be discriminated as naked-eye spots. These spots or groups of spots have areas of not less than 500 millionths of the sun's hemisphere or about 585 million square miles. The latest of these large spots is now crossing the sun's disk, from August 25 until September 6, with central meridian passage on August 30.7 U.T. Its growth to a large spot with multiple umbræ was considerable between August 27, when its area measured 400 millionths, and August 29, when it had increased to 900 millionths. The spot was surrounded by extensive faculæ, as seen in integrated light, and by flocculi as seen in hydrogen light $(H \alpha)$ or in that of ionized calcium ( $\mathbf{H}$ and $\mathbf{K}$ ). There was marked activity recorded with the spectrohelioscope at the Royal Observatory, Greenwich, on August 27 and 28-in particular a bright eruption, visible in $H \beta$ as well as in $H \alpha$, on August 28 between $10^{\mathrm{h}}$ and $11 \frac{1}{2}$ h.

\section{Announcements}

Following her record-breaking westbound passage across the Atlantic from Bishop Rock to the Ambrose Lightship, the Queen Mary has recently beaten the eastbound record. She passed Bishop Rock at $7.12 \mathrm{hr}$. G.M.T. on August 30, having. taken 3 days $23 \mathrm{hr}$. $57 \mathrm{~min}$. for the crossing. The average speed for the voyage of 2,939 miles was 30.63 knots, as compared with the average of $30 \cdot 31$ knots for the 3,015 miles which gave the Normandie the blue riband of the North Atlantic in June, 1935.

A Worlo Peace Conference is being held at Brussels on September 3-6. It has been organized by the International Peace Campaign; the Viscount
Cecil and Pierre Cot are joint presidents ; Miss Rose Manus, 48 Boulevard Botanique, Brussels, is the international secretary; Dame Adelaide Livingstone is vice-chairman of the British National Committee, which has its office at 27 Chester Terrace, Eaton Square, S.W.1. The Congress has special committees on medicine, science and education, and will raise general points, too, likely to be of interest to scientific workers.

Dr. Friedrich Küstrer, of Mehlem a. Rh., professor of astronomy and formerly director of the observatory of Bonn University, celebrated his eightieth birthday on August 28.

AN Institute for Industrial Medicine has recently been inaugurated in Milan.

The twenty-fifth Congress of the German Society of Legal and Social Medicine will be held at Dresden on September 17-19. Further information can be obtained from Dr. Schrader, Lahnstrasse 9, Marburg a.d. Lahn.

The Association for Photographic and Cinematographic Documentation in Science will hold a Congress in Paris on October 9-15. Further information can be obtained from Dr. Claoué, rue Scheffer 39, Paris, $16^{\mathrm{e}}$.

Erratium.-In the letter entitled "Measurements of Cosmic Rays in a Deep Mine" by Drs. J. Bamóthy and M. Forró in Nature of August 22, p. 325, lines 9 and 15 , for " $2,500 \mathrm{~m}$." read " $1,500 \mathrm{~m}$." ; line 15 , for " $0 \cdot 09$ " read " $0 \cdot 18$ ".

Applications are invited for the following appointments, on or before the dates mentioned :

A lecturer in electrical engineering in the Borough Polytechnic, London, S.E.1-The Principal (Septem. ber 9).

A lecturer in mechanical engineering in the Hands. worth Technical College, Golds Hill Road, Handsworth, Birmingham-The Principal (September 12).

A junior bacteriologist in the University of Bristol -The Registrar (September 12).

A vice-principal (industrial and/or mining engineering) of the Wakefield Technical College-The Director of Education, Education Department, 27 King Street, Wakefield (September 14).

An assistant lecturer in mathematics in the University of Sheffield-The Registrar (September 15).

An investigator for research in problems of falls of ground and haulage in coal mines to the Safety in Mines Research Board-The Under Secretary for Mines, Establishment Branch, Mines Department, Dean Stanley Street, London, S.W.1 (September 19).

A demonstrator in mechanical engineering in the University of Leeds--The Registrar (September 21).

A regius professor of natural history in the Uni. versity of Aberdeen-The Private Secretary, Scottish Office, Whitehall, London, S.W.1 (October 31). 